\title{
Diet supplementation with thyme oil and its main component thymol failed to favorably alter rumen fermentation, improve nutrient utilization, or enhance milk production in dairy cows
}

\section{Benchaar* (1)}

Agriculture and Agri-Food Canada, Sherbrooke Research and Development Centre, 2000 College Street, Sherbrooke, QC, Canada J1M 0C8

\begin{abstract}
Phenolic compounds and essential oils with high content of phenolic compounds have been reported to exert antimicrobial activities in vitro. The objective of this study was to determine the effects of dairy cow diet supplementation with thyme oil and its main component thymol on intake and total-tract apparent digestibility of nutrients, rumen fermentation characteristics, ruminal protozoa, nitrogen excretion, and milk production. For this aim, we used 8 multiparous, ruminally cannulated Holstein cows in a replicated $4 \times 4$ Latin square design ( $28 \mathrm{~d}$ periods), balanced for residual effects. Cows were fed 1 of the 4 following experimental treatments: total mixed ration (TMR) with no additive (control); TMR + monensin $[24 \mathrm{mg} / \mathrm{kg}$ of dry matter (DM)]; TMR + thyme oil (50 mg/kg of DM); and TMR + thymol $(50 \mathrm{mg} / \mathrm{kg}$ of DM). Compared with the control diet, feeding thyme oil or thymol had no effect on DM intake, nutrient total-tract apparent digestibility, total $\mathrm{N}$ excretion, ruminal $\mathrm{pH}$, ammonia concentration, total volatile fatty acid (VFA) concentration, or acetate:propionate ratio. Ruminal protozoa density was not modified by thyme oil, but decreased with thymol supplementation. Supplementation with thyme oil or thymol did not affect milk production, milk composition, or efficiency of milk production. Neither thyme oil nor thymol affected efficiency of dietary $\mathrm{N}$ use for milk $\mathrm{N}$ secretion (N intake/milk N). Supplementation with monensin tended to decrease DM intake $(-1.2 \mathrm{~kg} / \mathrm{d})$ and milk fat yield. Total-tract apparent digestibility of nutrients did not differ between cows fed monensin and cows fed the control diet. Total VFA concentration was not changed by monensin supplementation compared with control, but adding monensin shifted the VFA profile toward more propionate and less acetate, resulting in a decrease of acetate:propionate ratio. Protozoa
\end{abstract}

Received February 19, 2020.

Accepted August 16, 2020.

*Corresponding author: chaouki.benchaar@canada.ca density and ammonia concentration were lower in the ruminal content of cows fed monensin compared with that of cows fed the control diet. Total $\mathrm{N}$ excretion was not affected by monensin supplementation. Likewise, efficiency of use of dietary $\mathrm{N}$ for milk $\mathrm{N}$ secretion was unchanged in cows fed monensin. The results of this study contrasted with the claimed in vitro antimicrobial activity of thyme oil and thymol: we observed no positive effects on rumen metabolism (i.e., $\mathrm{N}$ and VFA) or milk performance in dairy cows. Under the conditions of this study, including thyme oil or thymol at 50 $\mathrm{mg} / \mathrm{kg}$ of DM had no benefits for rumen fermentation, nutrient utilization and milk performance in dairy cows. Key words: essential oils, rumen fermentation, nutrient utilization, milk production

\section{INTRODUCTION}

Over the last decade, the use of essential oils (EO) as alternatives to antimicrobials commonly used in livestock production has generated a lot of excitement. This interest has arisen mainly since the implementation of regulations that forbid the use of antimicrobials in Europe (European Union, 2003), and also because of increasing worldwide pressure from society and health authorities to reduce feed antibiotics in livestock production. As a consequence, scientists and the livestock feed industry have been actively searching for the best EO or EO compounds for use in ruminant nutrition (Patra and Saxena, 2009; Benchaar and Greathead, 2011; Cobellis et al., 2016).

Research efforts into EO have relied mostly on in vitro techniques, particularly batch cultures, to investigate the antimicrobial properties of $\mathrm{EO}$ in the rumen (Benchaar et al., 2008). In this regard, several in vitro studies using mainly batch-culture techniques have reported that phenolic compounds such as thymol, or EO with a high content of phenolic compounds such as thyme oil, exhibit antimicrobial activities in the rumen (Benchaar and Greathead, 2011). From a nutritional point view (i.e., energy and $\mathrm{N}$ metabolism), EO would 
be beneficial if they reduce protein degradation [i.e., decrease ammonia $\left(\mathrm{NH}_{3}\right)$ production], increase (or do not change) VFA production, and shift VFA patterns toward more propionate and less acetate production (Benchaar et al., 2008; Benchaar et al., 2009). However, a decrease in total VFA production (which is a reflection of feed digestion in the rumen) following EO supplementation would be energetically disadvantageous, given that VFA are the main source of energy to the ruminant animal.

Among EO and EO compounds, thyme oil and thymol (a phenolic monoterpene) have received much attention because of their potential antimicrobial activities in the rumen (Calsamiglia et al., 2007; Benchaar and Greathead, 2011; Cobellis et al., 2016). Macheboeuf et al. (2008) demonstrated in vitro that the antimicrobial activity of thyme oil in ruminal fluid is largely due to its main compound, thymol, although other compounds such as $p$-cymene and carvacrol may also be present at lower concentrations (Martínez et al., 2006). Castillejos et al. (2006) showed in batch cultures (24 h) that thymol (500 or $5,000 \mathrm{mg} / \mathrm{L}$ ) decreased $\mathrm{NH}_{3}$ and branchedchain VFA concentrations, which is an indication that the deamination process has been inhibited. When added at $500 \mathrm{mg} / \mathrm{L}$ in a continuous-culture system (9-d incubation), thymol did not affect $\mathrm{NH}_{3}$ concentration but did increase the accumulation of large and small $\mathrm{N}$ peptides, suggesting a stimulation of ruminal proteolysis and peptidolysis processes. In another study by Castillejos et al. (2008), the addition of 5, 50, and 500 $\mathrm{mg} / \mathrm{L}$ of thyme oil reduced $\mathrm{NH}_{3}$ concentration but had no effect on branched-chain VFA molar proportion in $24 \mathrm{~h}$ batch cultures. Macheboeuf et al. (2008) demonstrated in vitro the inhibitory effects of thyme oil and thymol on protein degradation as reflected by decreases in the production of $\mathrm{NH}_{3}$ and branched-chain VFA, an end product of deamination in the rumen.

Thyme oil and thymol have also been reported to affect VFA both in vitro and in vivo. For instance, Castillejos et al. (2008) observed that thyme oil increased total VFA concentration in $24 \mathrm{~h}$ batch fermentation, which is energetically beneficial to the ruminant animal. Khorrami et al. (2015) reported an increase in the molar proportion of propionate in ruminal fluid collected from beef cattle fed diets supplemented with thymol. The increase in the molar proportion of propionate would be beneficial if it were accompanied by increased propionate production, because propionate is the main precursor of glucose for ruminants (Rigout et al., 2003; Lemosquet et al., 2004).

Nevertheless, the effects of thyme oil and thymol on ruminal $\mathrm{N}$ metabolism have been variable among studies. Indeed, in contrast to findings reported in the studies cited above (Castillejos et al., 2006, 2008; Ma- cheboeuf et al., 2008), other studies in vitro (Benchaar et al., 2007a; Hristov et al., 2008) and in vivo (Khorrami et al., 2015) have reported no effect of thymol or thyme oil on ruminal N metabolism. Likewise, contrary to the positive changes in VFA reported by Castillejos et al. (2008) and Khorrami et al. (2015), other studies (Martínez et al., 2006; Benchaar et al., 2007a) reported undesirable effects on ruminal VFA (total concentration and profile) when they evaluated thyme oil or thymol in batch cultures. These contradictory responses of rumen metabolism to thyme oil and thymol suggest that further research is needed to evaluate the potential of thyme oil and thymol as rumen fermentation modulators. In addition, with the exception of the study by Khorrami et al. (2015) on beef cattle, no other studies have investigated the effects of thyme oil in live ruminants, and to the best of our knowledge, none have been done on thyme oil and thymol in dairy cows. Based on these findings from the literature, we hypothesized that supplying thyme oil and thymol in dairy cow diets might enhance efficiency of $\mathrm{N}$ and energy utilization in the rumen by reducing protein degradation and increasing energy supply (i.e., VFA) to dairy cows. These changes would have a positive effect on the productivity of dairy cows. Accordingly, the objective of the present work was to determine the effects of diet supplementation with thyme oil and thymol on intake and total-tract apparent digestibility of nutrients, $\mathrm{N}$ excretion, ruminal fermentation characteristics, protozoa, and milk production in lactating dairy cows.

\section{MATERIALS AND METHODS}

\section{Cows, Experimental Design, and Treatments}

We used 8 multiparous ruminally cannulated Holstein cows in a replicated $4 \times 4$ Latin square design, balanced for residual effects (Cochran and Cox, 1957). At the beginning of the experiment, cows averaged (mean $\pm \mathrm{SD}$ ) $62 \pm 11$ DIM, $41.4 \pm 3.36 \mathrm{~kg}$ of milk yield, and $682 \pm 57 \mathrm{~kg}$ of BW. During the trial, cows were housed in individual tie stalls and had free access to water. Cows were fed (ad libitum; $5 \%$ orts, as-fed basis) 1 of the 4 following experimental treatments: TMR with no additive (control); TMR + monensin $(24 \mathrm{mg} /$ $\mathrm{kg}$ of DM); TMR + thyme oil (50 mg/kg of DM); and TMR + thymol $(50 \mathrm{mg} / \mathrm{kg}$ of DM). The composition (ingredient and chemical) of the basal diet is shown in Table 1 . The thyme oil (containing 50\% thymol) and thymol (>98\% purity) were from Phodé (ZI Albipôle, Terssac, France), and the monensin (Rumensin 80) was from Elanco Animal Health Division Eli Lilly Canada Inc. (Guelph, ON, Canada). The doses of thyme oil and thymol were set in accordance with supplier recommen- 
Table 1. Ingredient and chemical composition of the TMR (basal diet)

\begin{tabular}{lc}
\hline Item (\% of DM, unless otherwise noted) & Amount \\
\hline Ingredient & \\
Alfalfa silage & 24.8 \\
Corn silage & 24.9 \\
Corn grain, rolled & 24.6 \\
Soybean meal, 48\% solvent-extracted & 14.7 \\
Beet pulp, dehydrated & 3.79 \\
Timothy hay, chopped & 3.70 \\
Mineral and vitamin supplement ${ }^{1}$ & 1.85 \\
Protein supplement $^{2}$ & 1.16 \\
Calcium carbonate & 0.43 \\
Chemical composition & \\
OM & 92.8 \\
CP & 16.5 \\
NDF & 33.7 \\
ADF & 21.4 \\
Starch & 21.7 \\
Ether extract & 2.41 \\
Gross energy (Mcal/kg of DM) & 4.35 \\
NE $_{\mathrm{L}}^{3}$ (Mcal/kg of DM) & 1.60 \\
\hline
\end{tabular}

${ }^{1}$ Contained $12.5 \%$ Ca, 6.80\% P, 6.81\% Mg, 2.49\% S, $7.72 \%$ Na, $1.97 \%$ $\mathrm{K}, 2,877 \mathrm{mg} / \mathrm{kg} \mathrm{Fe}, 3,777 \mathrm{mg} / \mathrm{kg} \mathrm{Zn}, 620 \mathrm{mg} / \mathrm{kg} \mathrm{Cu}, 2,520 \mathrm{mg} \mathrm{Mn}, 96$ $\mathrm{mg} / \mathrm{kg} \mathrm{I}, 83 \mathrm{mg} / \mathrm{kg} \mathrm{Co}, 27.8 \mathrm{mg} / \mathrm{kg}$ Se, $628,000 \mathrm{IU} / \mathrm{kg}$ of vitamin A, $81,000 \mathrm{UI} / \mathrm{kg}$ of vitamin $\mathrm{D}$, and $3,739 \mathrm{IU} / \mathrm{kg}$ of vitamin $\mathrm{E}$.

${ }^{2}$ Contained $20.8 \%$ corn gluten meal, $28.3 \%$ soybean meal Trituro (SoyaExcel, Saint-Charles-Sur-Richelieu, QC, Canada), 16.7\% canola meal, and $34.2 \%$ dried corn distillers grains.

${ }^{3}$ Calculated using values from National Research Council (2001) tables.

dations. The feed additives were thoroughly mixed with a portion of the concentrate and incorporated into the TMR to achieve the appropriate feeding rate.

Adaptation to experimental treatments occurred from d 1 to d 18, ruminal sampling on d 19 and d 20 , and sampling of milk, feces, and urine from d 21 to d 28. Animal procedures were conducted under the approval of the local institutional animal care committee and were in accordance with the guidelines of the Canadian Council on Animal Care (2009).

\section{Intake, Total-Tract Apparent Digestibility, and Fecal and Urinary Nitrogen Excretion}

Diets were offered in 2 equal meals twice daily (0900 and $1900 \mathrm{~h}$ ), and feed consumption was determined daily by weighing feeds offered to cows and orts. Samples of the TMR, ingredients, and orts were collected daily (d 21 to d 28) and stored at $-20^{\circ} \mathrm{C}$. Samples were later thawed, composited by cow within period, freeze-dried, and ground to pass a 1-mm screen using a Wiley mill (standard model 4; Arthur H. Thomas, Philadelphia, PA). The ground samples were subsequently analyzed for DM, OM, total N, NDF, ADF, gross energy (GE), starch, and ether extract.

Total collection of feces and urine was performed by fitting cows with harnesses and tubes allowing for the separate collection of feces and urine. Total urine was collected in a reinforced plastic container via a Gooch tube (Premier Industrial Hose Manufacturing Ltd., Granby, QC, Canada) attached to the vulva of the cow with nylon netting covered with neoprene (Spall Bowan Ltd., Guelph, ON, Canada). An appropriate amount of sulfuric acid $(50 \% \mathrm{vol} / \mathrm{vol})$ was added to the container, to maintain $\mathrm{pH}<2.0$. A representative urine sample $(2 \%)$ was collected and kept frozen at $-20^{\circ} \mathrm{C}$ until analysis for total N. Feces were collected in plastic-lined plywood boxes placed behind the cows. Daily total feces were weighed and thoroughly mixed, and a representative sample $(2 \%)$ was collected, stored at $-20^{\circ} \mathrm{C}$, and then thawed, freeze-dried, and ground to pass a 1-mm screen using a Wiley mill. The samples were later analyzed for DM, OM, CP, NDF, and GE contents. Data of intake (DM and nutrients) and nutrient digestibility were averaged across days for statistical analysis.

\section{Ruminal Fermentation Characteristics and Protozoa Enumeration}

Collection of ruminal content for the determination of fermentation characteristics and protozoa enumeration was performed as described in detail in Benchaar et al. (2013). Ruminal fluid (250 mL) was collected from the anterior dorsal, anterior ventral, medium ventral, posterior dorsal, and posterior ventral rumen at 0 $\mathrm{h}$ (before) and 1, 2, 4, 6, and $8 \mathrm{~h}$ after the a.m. feeding using a $50-\mathrm{mL}$ syringe screwed to a stainless steel tube ending with a probe covered by a fine metal mesh (RT rumen fluid collection tube; Bar Diamond Inc., Parma, ID). Ruminal $\mathrm{pH}$ was measured immediately after sampling (Accumet pH meter; Fisher Scientific, Montreal, QC, Canada), and subsamples $(15 \mathrm{~mL})$ were acidified to $\mathrm{pH} 2$ with $50 \%$ sulfuric acid and frozen at $-20^{\circ} \mathrm{C}$ for later determination of $\mathrm{VFA}$ and $\mathrm{NH}_{3}$ concentrations.

Protozoa were quantified in ruminal content collected $4 \mathrm{~h}$ after the a.m. feeding. For this purpose, approximately $1 \mathrm{~L}$ of ruminal content was squeezed through 4 layers of cheesecloth, and a portion $(5 \mathrm{~mL})$ was preserved using $5 \mathrm{~mL}$ of methyl green formalin-saline solution (Ogimoto and Imai, 1981). Protozoa samples were kept at room temperature in darkness until quantification using a counting chamber (Neubauer Improved Bright-Line counting cell, 0.1-mm depth; Hausser Scientific, Horsham, PA).

\section{Milk Production and Milk Composition}

Cows were milked twice daily at 0730 and $1930 \mathrm{~h}$ in their stalls. Milk production was recorded at each milking, and data from the collection period (d 21 to $\mathrm{d} 28$ ) 
were used for statistical analysis. Milk samples taken from each cow at each milking were stored at $4^{\circ} \mathrm{C}$ with a preservative (2-bromo-2-nitropropan-1,3-diol) and sent to the Canadian Dairy Herd Improvement Association (Lactanet, Ste-Anne-de-Bellevue, QC, Canada) for analysis of fat, protein, lactose, and MUN. In total, 16 individual samples per cow and per period were analyzed for milk components. Daily milk composition was corrected for differences in milk yield between a.m. and p.m. milkings. Data of milk production and milk composition were averaged across days for statistical analysis.

\section{Chemical Analyses}

Dry matter content was determined by drying samples in a vacuum oven at $100^{\circ} \mathrm{C}$ overnight (AOAC International, 2005; method 934.01). Ash content was determined by incineration at $550^{\circ} \mathrm{C}$ overnight in a muffle furnace (AOAC International, 2005; method 942.05), and OM content was calculated as the difference between 100 and the percentage of ash. Crude protein $(\mathrm{N} \times 6.25)$ was determined using the macro-Kjeldahl procedure (AOAC International, 2005; method 954.01). The concentration of NDF was determined as described by Van Soest et al. (1991), with the use of sodium sulfite and the inclusion of heat-stable $\alpha$-amylase. The $\mathrm{ADF}$ content was determined according to the AOAC International (2005; method 973.18). The NDF and $\mathrm{ADF}$ procedures were adapted for use in an Ankom ${ }^{200}$ Fiber Analyzer (Ankom Technology Corp., Macedon, NY). The concentration of starch was determined colorimetrically according to the AOAC International (2005; method 996.11). Ether extract was determined using the Soxtec 2050 extraction systems (Foss, Höganäs, Sweden), according to the AOAC International (2005; method 920.39). Gross energy was determined using an oxygen bomb calorimeter (model 6200; Parr Instrument Company, Moline, IL). The concentration of total $\mathrm{N}$ in acidified urine samples was determined by micro-Kjeldahl analysis (AOAC International, 2005). Frozen ruminal samples collected for ammonia analysis were thawed and centrifuged $(10,000 \times g ; 15 \mathrm{~min})$, and the supernatant was analyzed using the method described by Weatherburn (1967), modified for use with a microplate spectrophotometer (MRX Microplate Reader, Dynatech Laboratories, Chantilly, VA). Samples of ruminal fluid preserved for VFA analysis were thawed and centrifuged $(10,000 \times g ; 15 \mathrm{~min})$, and the supernatant was analyzed for VFA using a gas chromatograph. The gas chromatograph was equipped with a flame ionization detector and auto-injector $(6850$ network GC system; Agilent Technologies, Mississauga, ON, Canada) fitted with DB-FFAP column (30 $\mathrm{m} \times$
$0.250 \mathrm{~mm} \times 0.25 \mu \mathrm{m}$; Agilent Technologies). Fat, protein, lactose and urea $\mathrm{N}$ in milk samples were analyzed by infrared spectroscopy (System 4000 Milkoscan; Foss Electric of Hillerød, Denmark).

\section{Statistical Analyses}

Data were analyzed as a replicated $4 \times 4$ Latin square design using the MIXED procedure in SAS (SAS Inst. Inc., Cary, NC). The following model was used to account for residual effect:

$$
\mathrm{Y}_{i j k}=\mu+\mathrm{A}_{i}+\mathrm{P}_{j}+\mathrm{T}_{k}+\mathrm{R}_{j k^{\prime}}+\mathrm{e}_{i j k}
$$

where $\mathrm{Y}_{i j k}=$ dependent variable; $\mu=$ overall mean; $\mathrm{A}_{i}$ $=$ random effect of cow $(i=1$ to 8$) ; \mathrm{P}_{j}=$ fixed effect of period $(j=1$ to 4$) ; \mathrm{T}_{k}=$ fixed effect of treatment $(k=1$ to 4$) ; \mathrm{R}_{j k^{\prime}}=$ fixed residual effect of previous period $\left(\mathrm{R}_{j k^{\prime}}\right.$ $=0$ if period $=1 ; k^{\prime}$ is the treatment used in previous period); and $\mathrm{e}_{i j k}=$ residual error. If the residual effect was not significant $(P \geq 0.05)$, then $\mathrm{R}_{j k^{\prime}}$ was dropped from the model.

Data collected at different time intervals were analyzed as repeated measures using the following model:

$\mathrm{Y}_{i j k l}=\mu+\mathrm{A}_{i}+\mathrm{P}_{j}+\mathrm{T}_{k}+\mathrm{d}_{i j k}+\mathrm{H}_{l}+\mathrm{T} \times \mathrm{H}_{k l}+\mathrm{e}_{i j k l}$

where $\mathrm{Y}_{i j k l}=$ dependent variable; $\mu=$ overall mean; $\mathrm{A}_{i}=$ random effect of cow; $\mathrm{P}_{j}=$ fixed effect of period; $\mathrm{T}_{k}=$ fixed effect of treatment; $\mathrm{d}_{i j k}=$ random error associated with the experimental unit; $\mathrm{H}_{l}=$ fixed effect of sampling time $(l=0$ to 6$) ; \mathrm{T} \times \mathrm{H}_{k l}=$ fixed effect of sampling time $\times$ treatment interaction; and $\mathrm{e}_{i j k l}=$ residual error.

Differences between treatments were declared significant at $P \leq 0.05$ and tendency at $0.05<P \leq 0.10$ using the Tukey correction for multiple comparisons.

\section{RESULTS}

\section{Intake and Total-Tract Apparent Digestibility}

Data of the effect of experimental treatments on intake and total-tract apparent digestibility of nutrients are shown in Table 2. Dry matter intake was not significantly affected by diet supplementation with the feed additives, although it tended $(P=0.07)$ to be lower $(-5 \%)$ for cows fed monensin versus control, and tended $(P=0.10)$ to increase $(+5 \%)$ for cows fed monensin compared with cows fed thyme oil. The same trends were observed for intake of OM (monensin vs. control, $P=0.06$; monensin vs. thyme oil, $P=0.10$ ). Intake of $\mathrm{CP}$ was lower $(P<0.05)$ for cows fed monensin compared with cows fed the control diet, but did 
Table 2. Intake $(\mathrm{kg} / \mathrm{d}$, unless otherwise noted) and total-tract apparent digestibility of nutrients in lactating cows fed a TMR without supplementation (control), or supplemented with monensin, thyme oil, or thymol

\begin{tabular}{|c|c|c|c|c|c|c|}
\hline \multirow[b]{2}{*}{ Item } & \multicolumn{4}{|c|}{ Treatment } & \multirow[b]{2}{*}{ SEM } & \multirow[b]{2}{*}{$P$-value } \\
\hline & Control & Monensin & $\begin{array}{c}\text { Thyme } \\
\text { oil }\end{array}$ & Thymol & & \\
\hline \multicolumn{7}{|l|}{ Intake } \\
\hline DMI & 24.9 & 23.7 & 24.8 & 24.3 & 0.31 & 0.05 \\
\hline $\mathrm{OM}$ & 23.2 & 22.0 & 23.0 & 22.5 & 0.29 & 0.05 \\
\hline $\mathrm{CP}$ & $4.2^{\mathrm{a}}$ & $3.9^{\mathrm{b}}$ & $4.2^{\mathrm{a}}$ & $4.1^{\mathrm{ab}}$ & 0.07 & 0.03 \\
\hline NDF & 8.3 & 7.9 & 8.3 & 8.0 & 0.14 & 0.08 \\
\hline Gross energy (Mcal/d) & 108 & 104 & 108 & 106 & 1.32 & 0.07 \\
\hline \multicolumn{7}{|l|}{ Digestibility (\%) } \\
\hline DM & 66.8 & 66.8 & 66.8 & 66.0 & 0.40 & 0.49 \\
\hline $\mathrm{OM}$ & 68.2 & 68.0 & 68.3 & 67.3 & 0.41 & 0.38 \\
\hline $\mathrm{CP}$ & 65.6 & 65.0 & 65.7 & 65.1 & 0.51 & 0.67 \\
\hline $\mathrm{NDF}$ & 49.4 & 49.0 & 49.5 & 46.8 & 0.96 & 0.19 \\
\hline Gross energy & 65.9 & 65.5 & 65.8 & 65.1 & 0.45 & 0.58 \\
\hline
\end{tabular}

${ }_{\mathrm{a}, \mathrm{b}}$ Means within a row with different superscripts differ $(P<0.05)$.

not differ for thyme oil versus control, or for thymol versus control. Although feeding monensin instead of thyme oil caused a decrease $(P<0.05)$ in $\mathrm{CP}$ intake, we observed no effect when cows were fed monensin versus thymol. Intake of $\mathrm{CP}$ was not modified when cows were fed thyme oil versus thymol. Intake of NDF and GE were unaffected by diet supplementation with feed additives, although cows fed monensin tended $(P$ $=0.08$ ) to consume less GE than cows fed the control diet. Total-tract apparent digestibility of DM, OM, CP, $\mathrm{NDF}$, and GE was not changed by the addition of monensin, thyme oil, or thymol in the diet.

\section{Nitrogen Excretion}

Data of the effect of experimental treatments on $\mathrm{N}$ excretion are presented in Table 3. Dietary $\mathrm{N}$ intake was not affected by feeding cows thyme oil or thymol compared with control, but cows fed monensin had lower $(P<0.01) \mathrm{N}$ intake than cows fed the control diet. Intake of $\mathrm{N}$ decreased $(P=0.02)$ for cows fed monensin compared with cows fed thyme oil. However, $\mathrm{N}$ intake did not differ when cows were fed monensin compared with thymol.

We observed no difference in the amount $(\mathrm{g} / \mathrm{d})$ of $\mathrm{N}$ excreted daily in feces when cows were fed thyme oil or thymol compared with control. The amount of $\mathrm{N}$ excreted in feces was lower $(P=0.01)$ for cows fed monensin compared with control. Daily fecal N was not changed by feeding cows monensin versus thymol, but it tended $(P=0.08)$ to decrease when their diet was supplemented with monensin versus thyme oil. Fecal N expressed as a proportion of $\mathrm{N}$ intake was not changed by diet supplementation with feed additives. Urinary $\mathrm{N}$ (expressed in grams per day or as a proportion of $\mathrm{N}$ intake) was not modified by the presence of additives in the diet. Similarly, total N excretion (i.e., sum of fecal $\mathrm{N}$ and urinary $\mathrm{N}$; expressed as grams per day or

Table 3. Nitrogen excretion in lactating cows fed a TMR without supplementation (control), or supplemented with monensin, thyme oil, or thymol

\begin{tabular}{|c|c|c|c|c|c|c|}
\hline \multirow[b]{2}{*}{ Item } & \multicolumn{4}{|c|}{ Treatment } & \multirow[b]{2}{*}{ SEM } & \multirow[b]{2}{*}{$P$-value } \\
\hline & Control & Monensin & $\begin{array}{c}\text { Thyme } \\
\text { oil }\end{array}$ & Thymol & & \\
\hline Intake N (g/d) & $671^{\mathrm{a}}$ & $624^{\mathrm{b}}$ & $670^{\mathrm{a}}$ & $649^{\mathrm{ab}}$ & 11.0 & 0.03 \\
\hline \multicolumn{7}{|l|}{ Fecal N } \\
\hline $\mathrm{g} / \mathrm{d}$ & $231^{\mathrm{a}}$ & $219^{\mathrm{b}}$ & $230^{\mathrm{ab}}$ & $226^{\mathrm{ab}}$ & 2.9 & 0.05 \\
\hline$\% \mathrm{~N}$ intake & 34.4 & 35.0 & 34.3 & 34.9 & 0.51 & 0.67 \\
\hline \multicolumn{7}{|l|}{ Urinary N } \\
\hline $\mathrm{g} / \mathrm{d}$ & 204 & 206 & 211 & 203 & 4.0 & 0.56 \\
\hline$\% \mathrm{~N}$ intake & 30.3 & 32.9 & 31.6 & 31.5 & 0.85 & 0.24 \\
\hline \multicolumn{7}{|l|}{ Total N excretion } \\
\hline $\mathrm{g} / \mathrm{d}$ & 435 & 425 & 440 & 429 & 5.4 & 0.24 \\
\hline$\% \mathrm{~N}$ intake & 64.8 & 68.1 & 65.7 & 66.2 & 1.25 & 0.35 \\
\hline
\end{tabular}

${ }^{\mathrm{a}, \mathrm{b}}$ Means within a row with different superscripts differ $(P<0.05)$. 
Table 4. Ruminal fermentation characteristics and protozoa density in lactating cows fed a TMR without supplementation (control), or supplemented with monensin, thyme oil, or thymol

\begin{tabular}{|c|c|c|c|c|c|c|}
\hline \multirow[b]{2}{*}{ Item } & \multicolumn{4}{|c|}{ Treatment } & \multirow[b]{2}{*}{ SEM } & \multirow[b]{2}{*}{$P$-value } \\
\hline & Control & Monensin & $\begin{array}{c}\text { Thyme } \\
\text { oil }\end{array}$ & Thymol & & \\
\hline $\mathrm{pH}$ & 6.24 & 6.24 & 6.25 & 6.19 & 0.028 & 0.48 \\
\hline Total VFA $(\mathrm{m} M)$ & 130 & 128 & 126 & 132 & 2.9 & 0.43 \\
\hline \multicolumn{7}{|l|}{ VFA $(\mathrm{mol} / 100 \mathrm{~mol})$} \\
\hline Acetate & $61.8^{\mathrm{a}}$ & $60.4^{\mathrm{b}}$ & $61.5^{\mathrm{ab}}$ & $60.8^{\mathrm{ab}}$ & 0.33 & 0.03 \\
\hline Propionate & $20.6^{\mathrm{b}}$ & $23.0^{\mathrm{a}}$ & $21.0^{\mathrm{b}}$ & $21.5^{\mathrm{b}}$ & 0.34 & $<0.01$ \\
\hline Butyrate & $12.9^{\mathrm{a}}$ & $12.0^{\mathrm{b}}$ & $12.7^{\mathrm{a}}$ & $12.8^{\mathrm{a}}$ & 0.17 & 0.01 \\
\hline BCVFA $^{1}$ & 2.46 & 2.59 & 2.56 & 2.54 & 0.065 & 0.54 \\
\hline Valerate & 1.46 & 1.42 & 1.48 & 1.52 & 0.026 & 0.09 \\
\hline Caproate & 0.77 & 0.64 & 0.77 & 0.76 & 0.040 & 0.09 \\
\hline Acetate:propionate & $3.04^{\mathrm{a}}$ & $2.66^{\mathrm{b}}$ & $2.98^{\mathrm{a}}$ & $2.85^{\mathrm{ab}}$ & 0.066 & $<0.01$ \\
\hline Ammonia $(\mathrm{m} M)$ & $8.15^{\mathrm{a}}$ & $6.50^{\mathrm{b}}$ & $7.10^{\mathrm{ab}}$ & $7.83^{\mathrm{ab}}$ & 0.401 & 0.04 \\
\hline Protozoa $\left(\log _{10} / \mathrm{mL}\right)$ & $6.60^{\mathrm{a}}$ & $5.11^{\mathrm{b}}$ & $6.62^{\mathrm{a}}$ & $5.02^{\mathrm{b}}$ & 0.313 & 0.02 \\
\hline
\end{tabular}

${ }_{\mathrm{a}, \mathrm{b}}$ Means within a row with different superscripts differ $(P<0.05)$.

${ }^{1} \mathrm{BCVFA}=$ branched-chain VFA (sum of isobutyrate and isovalerate).

as a proportion of $\mathrm{N}$ intake) was not different among treatments.

\section{Ruminal Fermentation Characteristics and Protozoa}

Data of the effect of monensin, thyme oil, or thymol on ruminal fermentation characteristics and protozoa density are shown in Table 4. Neither ruminal pH nor total VFA concentrations were changed by diet supplementation with feed additives.

Acetate molar proportion was not different between cows fed thyme oil and cows fed the control diet, and was unchanged by feeding cows thymol versus control, or by feeding cows thymol versus thyme oil. Propionate molar proportion was unaffected by feeding cows thyme oil versus control, or by feeding thymol versus control. Similarly, molar proportion of propionate was not different between cows fed thyme oil versus thymol. As a consequence, compared with the control diet, the addition of thyme oil or thymol did not affect the acetate: propionate ratio.

Compared with the control diet, monensin decreased $(P<0.01)$ the molar proportion of acetate and increased $(P<0.01)$ that of propionate. Consequently, the acetate:propionate ratio was lower in cows fed monensin versus cows fed the control diet. Compared with the dietary addition of thyme oil, the addition of monensin had no effect on the molar proportion of acetate. We also observed an absence of effect on the molar proportion of acetate in cows fed thymol versus monensin. Consequently, the acetate:propionate ratio was unchanged by feeding cows monensin versus thyme oil, or by feeding monensin versus thymol.

Diet supplementation with monensin decreased $(P<$ $0.01)$ the molar proportion of butyrate compared with the control diet. Neither thyme oil nor thymol addition affected the molar proportion of butyrate compared with control. Compared with monensin, the dietary addition of thyme oil increased $(P<0.01)$ the molar proportion of butyrate; we observed the same effect $(P$ $<0.01$ ) when cows were fed monensin versus thymol. The molar proportion of branched-chain VFA was unaffected by any of the feed additives in the diet.

We observed no difference in ruminal $\mathrm{NH}_{3}$ concentration between cows fed the control diet and cows fed thyme oil, or between cows fed thymol and cows fed the control diet. We also observed a lack of effect on $\mathrm{NH}_{3}$ concentration when feeding thyme oil versus thymol. Supplementation with monensin decreased $(P<0.01)$ $\mathrm{NH}_{3}$ concentration compared with the control diet. In contrast, replacing monensin with thyme oil or thymol did not alter ruminal $\mathrm{NH}_{3}$ concentration.

Diet supplementation with monensin decreased $(P<$ 0.01) ruminal protozoa density compared with control. Protozoa density also decreased $(P=0.01)$ in cows fed thymol compared with the control diet. However, we observed no change in protozoa in cows were fed thyme oil versus control. Protozoa density was lower $(P=$ 0.01) in the ruminal fluid of cows supplemented with thymol compared with thyme oil. Cows fed monensin had lower protozoa than cows fed thyme oil, but we observed no difference between cows fed monensin and cows fed thymol.

\section{Milk Production and Milk Composition}

Data of the effect of experimental treatments on milk production and milk composition are shown in Table 5. None of the feed additives significantly affected yields of milk, FCM, or ECM. 
Table 5. Milk production and milk composition in lactating cows fed a TMR without supplementation (control), or supplemented with monensin, thyme oil, or thymol

\begin{tabular}{|c|c|c|c|c|c|c|}
\hline \multirow[b]{2}{*}{ Item } & \multicolumn{4}{|c|}{ Treatment } & \multirow[b]{2}{*}{ SEM } & \multirow[b]{2}{*}{$P$-value } \\
\hline & Control & Monensin & $\begin{array}{c}\text { Thyme } \\
\text { oil }\end{array}$ & Thymol & & \\
\hline \multicolumn{7}{|l|}{ Production $(\mathrm{kg} / \mathrm{d})$} \\
\hline Milk & 40.1 & 38.6 & 39.6 & 39.2 & 0.47 & 0.17 \\
\hline $\mathrm{FCM}^{1}$ & 37.7 & 36.0 & 37.4 & 37.3 & 0.53 & 0.13 \\
\hline $\mathrm{ECM}^{2}$ & 40.9 & 39.1 & 40.7 & 40.5 & 0.52 & 0.11 \\
\hline \multicolumn{7}{|l|}{ Composition (\%) } \\
\hline Fat & $3.61^{\mathrm{ab}}$ & $3.56^{\mathrm{b}}$ & $3.65^{\mathrm{ab}}$ & $3.70^{\mathrm{a}}$ & 0.028 & 0.01 \\
\hline Protein & 3.16 & 3.17 & 3.20 & 3.22 & 0.029 & 0.44 \\
\hline Lactose & 4.68 & 4.69 & 4.66 & 4.61 & 0.024 & 0.12 \\
\hline \multicolumn{7}{|l|}{ Yield (kg/d) } \\
\hline Fat & 1.45 & 1.37 & 1.44 & 1.44 & 0.024 & 0.10 \\
\hline Protein & 1.26 & 1.22 & 1.26 & 1.25 & 0.015 & 0.19 \\
\hline Lactose & 1.88 & 1.81 & 1.84 & 1.81 & 0.025 & 0.16 \\
\hline MUN (mg/dL) & 11.1 & 10.5 & 10.5 & 9.3 & 0.56 & 0.18 \\
\hline \multicolumn{7}{|l|}{ Feed efficiency } \\
\hline Milk/DMI & 1.62 & 1.63 & 1.60 & 1.60 & 0.024 & 0.66 \\
\hline FCM/DMI & 1.52 & 1.53 & 1.51 & 1.53 & 0.026 & 0.96 \\
\hline $\mathrm{ECM} / \mathrm{DMI}$ & 1.65 & 1.66 & 1.64 & 1.66 & 0.025 & 0.96 \\
\hline $\mathrm{N}$ milk/N intake $(\%)$ & 29.5 & 30.7 & 29.7 & 30.2 & 0.57 & 0.43 \\
\hline
\end{tabular}

Milk fat concentration was not significantly different between cows fed monensin and cows fed the control diet. The addition of thyme oil or thymol did not modify milk fat content versus control. Likewise, we observed no change in milk fat concentration between cows fed monensin and cows fed thyme oil. In contrast, cows consuming monensin had lower $(P<0.01)$ milk fat concentration than cows fed thymol. Neither milk protein content nor milk lactose concentrations were affected by feed additives in the diet.

Milk fat yield was not significantly affected by diet supplementation with feed additives, although it tended $(P=0.10)$ to be lower in cows fed monensin than in cows fed the control diet. Yields of milk protein and milk lactose were unaffected by diet supplementation with monensin, thyme oil, or thymol. Likewise, MUN concentration was not changed by any of the feed additives supplied in the diet. Neither feed efficiency $(\mathrm{kg}$ of milk/ $\mathrm{kg}$ of DM, $\mathrm{kg}$ of FCM $/ \mathrm{kg}$ of DMI, or $\mathrm{kg}$ of milk $\mathrm{ECM} / \mathrm{kg}$ of DMI) nor efficiency of use of dietary $\mathrm{N}$ for milk $\mathrm{N}$ secretion (milk $\mathrm{N} / \mathrm{N}$ intake) was affected by dietary treatments.

\section{DISCUSSION}

\section{Effect on Intake and Total-Tract Apparent Digestibility of Nutrients}

Compared with the control diet, supplementation with thyme oil or thymol had no effect on intake and total-tract apparent digestibility of DM, OM, CP, NDF, and GE. Rumen physical fill is one of the main regulators of DMI, particularly in high-producing dairy cows, and changes in DMI have been related to diet digestibility, particularly to that of the fiber fraction of the diet (Allen, 2000). A decrease in fiber digestibility can adversely affect DMI by limiting gut fill, because of the accumulation of nondigested material in the rumen (Allen, 2000). In contrast, an increase in fiber digestibility and the consequential reduction of physical fill in the rumen has been associated with increased DMI (Oba and Allen, 1999). In the present study, we observed no effect of thyme oil or thymol on DM and NDF digestibility, explaining the lack of effect of these additives on DMI. In some studies, the addition of EO, their components, or both in ruminant diets reduced palatability and decreased DMI (Klevenhusen et al., 2011; Hristov et al., 2013). In our study, diet supplementation with thyme oil or thymol did not affect palatability, as reflected by low daily refusals ( $\leq 5 \%$; data not shown) and made no change in DMI compared with control.

Our results of DMI were in accord with the findings of Khorrami et al. (2015), who observed no changes in DMI and nutrient total-tract apparent digestibility, despite a higher inclusion rate of thyme oil $(450 \mathrm{~g} / \mathrm{kg}$ of thymol) in a beef cattle diet ( 500 and $225 \mathrm{mg} / \mathrm{kg}$ of DM of thyme oil and thymol, respectively), compared with the feeding rate applied in our study. Likewise, the lack of effect of thyme oil or thymol on total-tract 
apparent digestibility agrees with the in vitro findings of Castillejos et al. (2006), when thymol was supplied at low doses ( 5 and $50 \mathrm{mg} / \mathrm{L}$ ) in continuous-culture fermentors. However, a higher supplementation level of thymol $(500 \mathrm{mg} / \mathrm{L})$ in the study of Castillejos et al. (2006) dramatically reduced nutrient (DM, OM, NDF, and ADF) digestibility. The in vitro dose of $500 \mathrm{mg} / \mathrm{L}$ applied by Castillejos et al. (2006) would correspond to an intake of $50 \mathrm{~g} / \mathrm{d}$ of thymol, assuming a rumen volume of $100 \mathrm{~L}$ for an average adult dairy cow. Such an amount is too high and is impractical for use in live animals because it has adverse effects on feed digestion and fermentation in the rumen (Yang et al., 2010; Patra and $\mathrm{Yu}, 2012$ ); it is not economically feasible (i.e., high cost of EO); palatability is a problem (Beauchemin et al., 2009; Benchaar et al., 2009); and it may be toxic in animals (Durmic and Blache, 2012; Yang et al., 2015; Horky et al., 2019).

Diet supplementation with monensin tended to decrease DMI by $1.2 \mathrm{~kg} / \mathrm{d}$, compared with the control diet. This finding disagrees with those of Benchaar (2016, 2020) and Grainger et al. (2010) when monensin was used at a similar concentration to that applied in the present study. Meta-analyses by Duffield et al. (2008) and Appuhamy et al. (2013) reported that monensin reduced DMI by 2.3 to $2.6 \%$ in dairy cows. However, DMI response to monensin supplementation in dairy cows has been variable among studies (Ipharraguerre and Clark; 2003), and this variation could be related to several factors, such as stage of lactation, composition of the diet, and duration of the trial. In our study, monensin supplementation had no effect on totaltract apparent digestibility of CP. The effect of the dietary addition of monensin on $\mathrm{CP}$ digestibility has been inconsistent among studies, ranging from no effect (Benchaar et al., 2006; Odongo et al., 2007) to an increase (Plaizier et al., 2000; Benchaar, 2020). This variability has been attributed to the composition of the diet (i.e., forage:concentrate ratio) and the monensin dosage rate (Benchaar et al., 2006; Benchaar, 2016).

\section{Effect on Ruminal pH, VFA, and Protozoa}

Supplementing thyme oil or thymol did not change ruminal $\mathrm{pH}$ and total VFA concentration, compared with the control diet. Ruminal total VFA concentration reflects extent of feed digestion in the rumen. In the present study, the digestibility of OM (particularly its fiber fraction) was not modified by thyme oil or thymol compared with control. This was consistent with the lack of effect on ruminal $\mathrm{pH}$ and total VFA concentration. Our findings of total VFA concentration agree with the results of Vakili et al. (2013) and Khorrami et al. (2015), who included thyme oil at 5 g/d (i.e., $617 \mathrm{mg} / \mathrm{kg}$ of DMI) and $500 \mathrm{mg} / \mathrm{kg}$ of DMI (i.e., $6 \mathrm{~g}$ /day) in growing bull calf and Holstein steer diets, respectively. However, our total VFA concentration results contradict those of Castillejos et al. (2008), who observed an increase in total VFA concentration following the addition of 5,50 , and $500 \mathrm{mg} / \mathrm{L}$ of thyme oil in $24 \mathrm{~h}$ batch cultures of ruminal fluid. In a previous in vitro study by the same authors (Castillejos et al., 2006), total VFA concentration was unaffected by the addition of 5 and $50 \mathrm{mg} / \mathrm{L}$ of thymol in continuous cultures, but it dramatically decreased at a higher supplementation dose $(500 \mathrm{mg} / \mathrm{L})$. Results from Castillejos et al. (2006) suggest that the effect of thymol on total VFA concentration may be dose-dependent. Moreover, other in vitro studies have proposed that the antimicrobial activity of thymol may be $\mathrm{pH}-$ and diet-dependent (Cardozo et al., 2005; Castillejos et al., 2006). Benchaar et al. (2007b) observed that supplying a mixture of EO compounds (thymol, eugenol, vanillin, limonene, and guaiacol) in an alfalfa-silage-based diet increased total VFA concentration, whereas adding the supplement in a corn-silage-based diet decreased total VFA concentration. Collectively, findings from these studies illustrate the importance of ensuring optimal conditions to allow thyme oil and thymol to exhibit their microbial activity in the rumen and enhance the efficiency of rumen fermentation. Finally, differences in rumen fermentation responses to thyme oil and thymol between in vivo and in vitro methodologies are due to higher in vitro doses compared with in vivo feeding rates (Benchaar et al., 2008, 2009). More importantly, this discrepancy is mainly related to the limitation of in vitro systems (i.e., short-term incubation, heavily buffered medium, inability to replicate the diversity and viability of the microbial populations, lack of absorption of fermentation end products) as reported by Benchaar et al. (2009) and Hristov et al. (2012).

Compared with the control diet, including thyme oil or thymol did not affect the molar proportion of acetate, in line with the absence of thyme oil and thymol effect on NDF digestibility. The molar proportion of propionate and the acetate:propionate ratio were also unchanged by these 2 treatments. The lack of effect on the molar proportion of acetate was consistent the unaffected NDF digestibility and in agreement with the findings of Khorrami et al. (2015) in beef cattle. However, our findings of the molar proportion of propionate do not corroborate those of Vakili et al. (2013), who observed an increase of propionate at the expense of acetate, resulting in a lower acetate:propionate ratio in growing bull calves fed thyme oil at $5 \mathrm{~g} / \mathrm{d}$. The dosage level used in the study of Vakili et al. (2013) was 4 times higher than that applied in our study (i.e., $1.2 \mathrm{~g} / \mathrm{d}$ ), at least partially explaining the discrepancy between the 
2 studies in VFA profile response to thyme oil supplementation. In our study, the diet contained $53 \%$ forages (DM basis), and ruminal $\mathrm{pH}$ in cows fed thyme oil or thymol averaged 6.2. In the study by Vakili et al. (2013), the diet contained $85 \%$ concentrate, and ruminal $\mathrm{pH}$ averaged 5.94. Such different experimental conditions further explain the different responses in VFA profile between our study and that of Vakili et al. (2013). Calsamiglia et al. (2007) reported that the effect of thymol on VFA profile was diet- and pH-dependent, because the acetate:propionate ratio increased when thymol was added in a 60:40 forage:concentrate diet at $\mathrm{pH} 6.4$ (high), but it decreased when thymol was incubated in ruminal fluid from cattle fed a 10:90 forage:concentrate diet at pH 5.5 (low). Juven et al. (1994) and Gutierrez et al. (2009) observed that the antimicrobial activity of thyme oil and thymol increased at acidic $\mathrm{pH}$ conditions. At low $\mathrm{pH}$ values, the thymol molecule is undissociated and more hydrophobic and dissolves better in the lipid bilayer of the bacterial membrane (Juven et al., 1994). In the present study, ruminal $\mathrm{pH}$ was not affected by thyme oil or thymol supplementation and was not acidic $(6.25$, on average), which probably made the rumen environment less favorable to allowing thyme oil and thymol to exert their activity against rumen bacteria. Based on these results, we are tempted to speculate that the use of thyme oil or thymol as feed additives in dairy cow rations may be more appropriate in dietary conditions that favor low $\mathrm{pH}$ (high-starch diet) rather than high $\mathrm{pH}$ (high-fiber diet). The relation between ruminal $\mathrm{pH}$ and its effects on EO antimicrobial activity merits more investigation, and further research is warranted to determine the optimal dose, dietary conditions and diet $\times$ dose interaction that would favorably alter VFA pattern in dairy cows fed thyme oil or thymol.

Compared with cows fed the control diet, ruminal protozoa density was not affected by the addition of thyme oil, but it decreased with the addition of thymol. Data on the effect of thyme oil or thymol on rumen protozoa are scarce. Protozoa density was not affected in studies where phenolic compounds (eugenol 25 to 75 $\mathrm{mg} / \mathrm{kg}$ of DM or carvacrol $50 \mathrm{mg} / \mathrm{kg}$ of DM) or EO with a high content of phenolic compounds (oregano oil 50 $\mathrm{mg} / \mathrm{kg}$ of DM) were fed to dairy cows (Benchaar et al., 2012, 2015; Benchaar, 2020). In Khorrami et al. (2015), supplementing the diet with $500 \mathrm{mg} / \mathrm{kg}$ of thyme oil strongly reduced ruminal protozoa in Holstein steers. The higher dose of thyme oil $(500 \mathrm{mg} / \mathrm{kg}$ of DM providing $225 \mathrm{mg} / \mathrm{kg}$ of DM of thymol) used in Khorrami et al. (2015) compared with the dose used in our study (50 $\mathrm{mg} / \mathrm{kg}$ of DM) may explain the difference in protozoa response to thyme oil supplementation between the 2 studies. It therefore appears that high doses of thyme oil or thymol are required to inhibit the growth and activity of rumen protozoal populations.

A common effect of dietary supplementation with monensin is the shift of VFA pattern toward propionate production at the expense of that of acetate, resulting in a decrease of the acetate:propionate ratio (Russell and Strobel, 1989). We also observed such a shift in the present study. Data from the literature show inconsistent effects of monensin on the acetate:propionate ratio in dairy cows, an inconsistency that has been related to the dose of monensin, diet composition (i.e., forage: concentrate ratio), and the source of starch (barley vs. corn) in the diet (Ramanzin et al., 1997; Jenkins et al., 2003; Broderick, 2004). The molar proportion of butyrate decreased in cows fed monensin compared with cows fed the control diet, and this decrease was in line with a reduction in butyrate-producing protozoa (Morgavi et al., 2012).

\section{Effect on Nitrogen Utilization}

Ruminal $\mathrm{NH}_{3}$ concentration was not different between cows fed thyme oil or thymol compared with cows fed the control diet, which was consistent with the lack of change in branched-chain VFA molar proportion, an end product of ruminal deamination. This absence of effect on $\mathrm{NH}_{3}$ concentration was also expected, because neither $\mathrm{N}$ intake nor $\mathrm{CP}$ total-tract apparent digestibility was modified by thyme oil or thymol supplementation. As discussed above, the $\mathrm{pH}$ conditions observed in this study may be another explanation for the absence of positive effects of thyme oil and thymol on rumen $\mathrm{N}$ metabolism. Our findings were in accord with those of Vakili et al. (2013) and Khorrami et al. (2015), who observed no change in ruminal $\mathrm{NH}_{3}$ concentration despite the inclusion of higher doses of thyme oil (617 and 500 $\mathrm{mg} / \mathrm{kg}$ of DM, respectively), compared with the dose in this study $(50 \mathrm{mg} / \mathrm{kg}$ of DM). Higher doses (i.e., 500 and $5,000 \mathrm{mg} / \mathrm{L}$ vs. 5 and $50 \mathrm{mg} / \mathrm{L}$ ) of thymol were applied by Castillejos et al. (2006) to achieve a decrease in $\mathrm{NH}_{3}$ concentration in $24 \mathrm{~h}$ batch-culture incubations. However, this inhibitory effect was not confirmed in the same study when 5,50 and $500 \mathrm{mg} / \mathrm{L}$ of thymol were administered in continuous-culture fermentors (Castillejos et al., 2006). These contradictions in results generated from the same laboratory indicate that the in vitro technique used (continuous culture vs. batch culture), and the length of incubation period ( $24 \mathrm{~h}$ vs. $9 \mathrm{~d}$ ), may greatly influence the effect of EO on ruminal $\mathrm{N}$ metabolism. A longer in vitro exposure of rumen microbes to EO (e.g., continuous fermentors: 9 d vs. batch cultures: $24 \mathrm{~h}$ ) may result in their adaptation to these secondary metabolites (Busquet et al., 2005a,b). 
Compared with the control diet, supplementation with thyme oil or thymol had no effect on $\mathrm{N}$ excretion (i.e., fecal, urinary, or total), consistent with the lack of effects of these 2 supplements on $\mathrm{N}$ intake, $\mathrm{CP}$ digestibility and ruminal $\mathrm{NH}_{3}$ concentration. Similarly, efficiency of dietary $\mathrm{N}$ use for milk $\mathrm{N}$ secretion (i.e., $\mathrm{N}$ milk $\div \mathrm{N}$ intake) was not changed by feeding cows thyme oil or thymol versus control. Information on the effect of thyme oil and its main component, thymol, on $\mathrm{N}$ utilization in dairy cows is nonexistent. Benchaar (2020) observed no change in fecal, urinary, or total N excretion in dairy cows supplemented with carvacrol (i.e., phenolic monoterpene) or oregano oil (containing $70 \%$ carvacrol).

Monensin has been used to improve efficiency of $\mathrm{N}$ via the reduction of dietary protein degradation in the rumen, mainly by inhibiting the deamination process (Russell and Strobel, 1989). In the present study, diet supplementation with monensin decreased ruminal $\mathrm{NH}_{3}$ concentration compared with the control diet. However, the reduction of ruminal $\mathrm{NH}_{3}$ concentration was not accompanied by a decrease in the molar proportion of branched-chain VFA. Branched-chain VFA are end products of deamination of AA, so these results suggest that the lower $\mathrm{NH}_{3}$ concentration cannot be explained by the inhibitory action of monensin on ruminal degradation of dietary $\mathrm{N}$. This decrease in ruminal $\mathrm{NH}_{3}$ concentration was actually related mainly to the lower $\mathrm{N}$ intake in cows fed monensin versus cows fed the control diet. It is equally possible that the decrease in $\mathrm{NH}_{3}$ concentration upon monensin supplementation could be related to a reduction in ruminal protozoa populations (Russell and Strobel, 1989; Sylvester et al., 2009). Decreased protozoa density has been associated with reduced $\mathrm{NH}_{3}$ concentration, apparently mainly due to a reduction of bacterial protein degradation (Williams and Coleman, 1992).

\section{Effect on Milk Production and Milk Composition}

Milk production was unaffected by thyme oil and thymol supplementation compared with control. Milk yield is driven mainly by DMI and nutrient supply. In several studies, milk production increased when DMI increased in dairy cows (Oba and Allen, 1999; Benchaar et al., 2013; Hassanat et al., 2017). In our study, neither DMI nor intake and digestibility of nutrients were changed by dietary addition of thyme oil or thymol, which explains the absence of change in milk production.

Milk fat percentage and yield remained unaffected when supplementing the diet with thyme oil or thymol versus control, which agreed with the lack of effect of thyme oil and thymol on the molar proportion of acetate, the main precursor of fat synthesis by the mammary gland. No data are available on the effects of thyme oil and thymol on milk fat concentration or yield. Nevertheless, Tekippe et al. (2011) reported an increase in milk fat content and yield, although the acetate molar proportion was unaffected in cows supplemented with oregano leaves $(500 \mathrm{~g} / \mathrm{d} ; 1.4 \% \mathrm{EO} ; 98.8 \%$ carvacrol). In contrast, using oregano extract $(10 \mathrm{~g} / \mathrm{d} ; 5 \%$ EO; $80 \%$ carvacrol), Kolling et al. (2018) observed a decrease in milk fat content that was related to a reduction in milk concentration of several short-chain fatty acids, although this is contradictory to their results of rumen VFA profile. Milk fat decrease has been associated with a shift in ruminal fatty acid biohydrogenation from the trans-11 pathway to the trans-10 pathway (lower trans-11/trans-10 ratio), leading to an increase in the accumulation of intermediates that inhibit milk fat synthesis by the mammary gland (Bauman et al., 2011). In our study, the trans-11/trans-10 ratio in milk fat was not changed by thyme oil or thymol versus control (2.81, 2.74, and 2.70, respectively; data not shown), which further explains the absence of an effect of thyme oil and thymol on milk fat.

Milk urea $\mathrm{N}$ was not changed by feeding thyme oil versus control or by feeding thymol versus control, consistent with the lack of changes in ruminal $\mathrm{NH}_{3}$ concentration and urinary $\mathrm{N}$ excretion. In contrast, Hristov et al. (2013) observed lower MUN in cows fed oregano leaves $(250,500$, and $750 \mathrm{~g} / \mathrm{d} ; 1.5 \% \mathrm{EO}, 78.5 \%$ carvacrol) compared with cows fed an unsupplemented diet, and this decrease in MUN was consistent with a reduction in ruminal $\mathrm{NH}_{3}$ concentration following diet supplementation.

In the present study, because yields of milk, fat, and protein were not affected by feeding cows thyme oil or thymol versus control, the production of FCM and ECM was unchanged. Because DM was also unaffected by thyme oil or thymol, feed efficiency $(\mathrm{kg}$ of milk $/ \mathrm{kg}$ of DMI, $\mathrm{kg}$ of FCM/ $\mathrm{kg}$ of DMI, or $\mathrm{kg}$ of ECM $/ \mathrm{kg}$ of DMI) was not different between cows fed the control diet and those fed thyme oil or thymol. Similar to our observations, other studies using phenolic compounds (e.g., eugenol, carvacrol) or EO with high concentration of phenolic compounds (e.g., oregano oil) also reported no modification in milk production, milk composition, or feed efficiency (Benchaar et al., 2012, 2015; Benchaar, 2020).

In the present study, dietary supplementation with monensin numerically decreased milk production $(-1.5$ $\mathrm{kg} / \mathrm{d}$ ), consistent with the tendency for lower DMI in cows fed monensin versus cows fed the control diet $(-1.2$ $\mathrm{kg} / \mathrm{d}$ ). Recently, Benchaar (2020) observed no change in milk production and DMI when monensin was supplied at the same dose used in the present study. In general, the use of monensin in dairy cow diets has 
been associated with improved feed efficiency as a result of a concomitant decrease in DMI and an increase in milk yield. In a meta-analysis, Duffield et al. (2008) reported that monensin reduced DMI by $0.3 \mathrm{~kg} / \mathrm{d}$, increased milk yield by $0.7 \mathrm{~kg} / \mathrm{d}$, and enhanced milk production efficiency by $2.5 \%$. It has been speculated that monensin increases milk production by improving energy efficiency via the shift of rumen fermentation toward the production of propionate (Duffield et al., 2008), and such an increase in propionate also occurred in our study. Propionate is a major precursor for gluconeogenesis in ruminants (Seal and Reynolds, 1993). In the present study, it seems that the increase in ruminal propionate proportion was not enough to alleviate the negative effect of monensin on milk yield.

Several studies have reported a decrease in milk fat yield, concentration, or both when monensin was fed to dairy cows, although the effect may vary with diet composition (Duffield et al., 2008). In our study, milk fat (content and yield) tended to decrease with monensin supplementation compared with the control diet. This decrease, if it was significant, can be explained by a slight but significant decrease in the molar proportion of acetate (i.e., the main fat precursor). Furthermore, it has been shown that monensin alters ruminal FA biohydrogenation by directing the ruminal fatty acid biohydrogenation process from the trans-11 pathway to the trans-10 pathway (Benchaar, 2020), which decreases milk fat yield (see discussion above). Such changes also occurred in our study: the trans-11/trans-10 ratio was lower in the milk fat of cows fed monensin versus cows fed the control diet ( 2.45 vs. 2.81 ; data not shown).

\section{CONCLUSIONS}

Diet supplementation with thyme oil or its main component thymol had no effect on the intake and digestibility of nutrients, $\mathrm{N}$ utilization, ruminal fermentation characteristics, or milk performance (production and efficiency). These findings contrasted with the reported in vitro ruminal antimicrobial activity of thyme oil and thymol and their positive effect on the efficiency of rumen fermentation. Based on these findings, and considering the experimental conditions of the present study, we conclude that no benefits for rumen fermentation, nutrient utilization, or milk performance in dairy cows can be expected from diet supplementation with thyme oil and thymol at $50 \mathrm{mg} / \mathrm{kg}$ of DMI.

\section{ACKNOWLEDGMENTS}

The author thanks L. Croteau (technical assistance), S. Méthot (help with statistical analyses), and the barn staff (care of the animals) from the Sherbrooke
Research and Development Centre (Agriculture and Agri-Food Canada, Sherbrooke, QC, Canada). The donation of thyme oil and thymol by Phodé (Albi, France) was much appreciated. Funding for the study was from Agriculture and Agri-Food Canada (Ottawa, ON, Canada). The author has not stated any conflicts of interest.

\section{REFERENCES}

Allen, M. S. 2000. Effects of diet on short-term regulation of feed intake by lactating dairy cattle. J. Dairy Sci. 83:1598-1624. https:// doi.org/10.3168/jds.S0022-0302(00)75030-2.

AOAC International. 2005. Official Methods of Analysis. 18th ed. AOAC International, Arlington, VA.

Bauman, D. E., K. J. Harvatine, and A. L. Lock. 2011. Nutrigenomics, rumen-derived bioactive fatty acids, and the regulation of milk fat synthesis. Annu. Rev. Nutr. 31:299-319. https://doi.org/10.1146/ annurev.nutr.012809.104648.

Beauchemin, K., T. A. McAllister, and S. M. McGinn. 2009. Dietary mitigation of enteric methane from cattle. Nutr. Natur. Resour. 4:1-18. https://doi.org/10.1079/PAVSNNR20094035.

Benchaar, C. 2016. Diet supplementation with cinnamon oil, cinnamaldehyde, or monensin does not reduce enteric methane production of dairy cows. Animal 10:418-425. https://doi.org/10.1017/ S175173111500230X.

Benchaar, C. 2020. Feeding oregano oil and its main component carvacrol does not affect ruminal fermentation, nutrient utilization, methane emissions, milk production, and milk fatty acid composition of dairy cows. J. Dairy Sci. 103:1516-1527. https://doi.org/10 .3168/jds.2019-17230.

Benchaar, C., S. Calsamiglia, A. V. Chaves, G. R. Fraser, D. Colombatto, T. A. McAllister, and K. A. Beauchemin. 2008. A review of plant-derived essential oils in ruminant nutrition and production. Anim. Feed Sci. Technol. 145:209-228. https://doi.org/10.1016/j .anifeedsci.2007.04.014.

Benchaar, C., A. V. Chaves, G. R. Fraser, K. A. Beauchemin, and T. A. McAllister. 2007a. Effects of essential oils and their components on in vitro rumen microbial fermentation. Can. J. Anim. Sci. 87:413-419. https://doi.org/10.4141/CJAS07012.

Benchaar, C., and H. Greathead. 2011. Essential oils and opportunities to mitigate enteric methane emissions from ruminants. Anim. Feed Sci. Technol. 166-167:338-355. https://doi.org/10.1016/j .anifeedsci.2011.04.024.

Benchaar, C., F. Hassanat, R. Gervais, P. Y. Chouinard, C. Julien, H. V. Petit, and D. I. Massé. 2013. Effects of increasing amounts of corn dried distillers grains with solubles in dairy cow diets on methane production, ruminal fermentation, digestion, $\mathrm{N}$ balance, and milk production. J. Dairy Sci. 96:2413-2427. https://doi.org/ 10.3168/jds.2012-6037.

Benchaar, C., F. Hassanat, and H. V. Petit. 2015. Dose-response to eugenol supplementation to dairy cow diets: Methane production, $\mathrm{N}$ excretion, ruminal fermentation, nutrient digestibility, milk production, and milk fatty acid profile. Anim. Feed Sci. Technol. 209:51-59. https://doi.org/10.1016/j.anifeedsci.2015.07.027.

Benchaar, C., A. N. Hristov, and H. Greathead. 2009. Essential oils as feed additives in animal nutrition. Pages 111-146 in Phytogenics in Animal Nutrition. T. Steiner, ed. Nottingham University Press, Nottingham, UK.

Benchaar, C., A. Lettat, F. Hassanat, W. Z. Yang, R. J. Forster, H. V. Petit, and P. Y. Chouinard. 2012. Eugenol for dairy cows fed low or high concentrate diets: Effects on digestion, ruminal fermentation characteristics, rumen microbial populations and milk fatty acid profile. Anim. Feed Sci. Technol. 178:139-150. https://doi .org/10.1016/j.anifeedsci.2012.10.005.

Benchaar, C., H. V. Petit, R. Berthiaume, D. R. Ouellet, J. Chiquette, and P. Y. Chouinard. 2007b. Effects of essential oils on digestion, ruminal fermentation, rumen microbial populations, milk produc- 
tion, and milk composition in dairy cows fed alfalfa silage or corn silage. J. Dairy Sci. 90:886-897. https://doi.org/10.3168/jds.S0022 -0302(07)71572-2.

Benchaar, C., H. V. Petit, R. Berthiaume, T. D. Whyte, and P. Y. Chouinard. 2006. Effects of addition of essential oils and monensin premix on digestion, ruminal fermentation, milk production, and milk composition in dairy cows. J. Dairy Sci. 89:4352-4364. https: //doi.org/10.3168/jds.S0022-0302(06)72482-1.

Broderick, G. A. 2004. Effect of low level monensin supplementation on the production of dairy cows fed alfalfa silage. J. Dairy Sci. 87:359-368. https://doi.org/10.3168/jds.S0022-0302(04)73175-6.

Busquet, M., S. Calsamiglia, A. Ferret, P. W. Cardozo, and C. Kamel. 2005a. Effects of cinnamaldehyde and garlic oil on rumen microbial fermentation in a dual flow continuous culture. J. Dairy Sci. 88:2508-2516. https://doi.org/10.3168/jds.S0022-0302(05)72928 -3 .

Busquet, M., S. Calsamiglia, A. Ferret, M. D. Carro, and C. Kamel. 2005b. Effect of garlic oil and four of its compounds on rumen microbial fermentation. J. Dairy Sci. 88:4393-4404. https://doi.org/ 10.3168/jds.S0022-0302(05)73126-X.

Calsamiglia, S., M. Busquet, P. W. Cardozo, L. Castillejos, and A. Ferret. 2007. Invited review: Essential oils as modifiers of rumen microbial fermentation. J. Dairy Sci. 90:2580-2595. https://doi .org/10.3168/jds.2006-644.

Canadian Council on Animal Care. 2009. CCAC Guidelines on: The Care and Use of Farm Animals in Research, Teaching and Testing. Canadian Council on Animal Care, Ottawa, Canada.

Cardozo, P. W., S. Calsamiglia, A. Ferret, and C. Kamel. 2005. Screening for the effects of natural plant extracts at different $\mathrm{pH}$ on in vitro rumen microbial fermentation of a high-concentrate diet for beef cattle. J. Anim. Sci. 83:2572-2579. https://doi.org/10.2527/ 2005.83112572x.

Castillejos, L., S. Calsamiglia, and A. Ferret. 2006. Effect of essential oils active compounds on rumen microbial fermentation and nutrient flow in in vitro systems. J. Dairy Sci. 89:2649-2658. https:// doi.org/10.3168/jds.S0022-0302(06)72341-4.

Castillejos, L., S. Calsamiglia, J. Martín-Tereso, and H. Ter Wijlen. 2008. In vitro evaluation of effects of ten essential oils at three doses on ruminal fermentation of high concentrate feedlot type diets. Anim. Feed Sci. Technol. 145:259-270. https://doi.org/10 .1016/j.anifeedsci.2007.05.037.

Cobellis, G., M. Trabalza-Marinucci, and Z. Yu. 2016. Critical evaluation of essential oils as rumen modifiers in ruminant nutrition: A review. Sci. Total Environ. 545-546:556-568. https://doi.org/10 .1016/j.scitotenv.2015.12.103.

Cochran, W. G., and G. M. Cox. 1957. Experimental Designs. 2nd ed. John Wiley \& Sons Inc., New York, NY.

Duffield, T. F., A. R. Rabiee, and I. J. Lean. 2008. A meta-analysis of the impact of monensin in lactating dairy cattle. Part 2. Production effects. J. Dairy Sci. 91:1347-1360. https://doi.org/10.3168/ jds.2007-0608.

Durmic, Z., and D. Blache. 2012. Bioactive plants and plant products: Effects on animal function, health and welfare. Anim. Feed Sci. Technol. 176:150-162. https://doi.org/10.1016/j.anifeedsci.2012 .07 .018 .

European Union. 2003. Regulation (EC) No 1831/2003 of the European Parliament and the Council of 22 September 2003 on additives for use in animal nutrition. Official J. Eur. Union. L268/36.

Grainger, C., R. Williams, R. J. Eckard, and M. C. Hannah. 2010. A high dose of monensin does not reduce methane emissions of dairy cows offered pasture supplemented with grain. J. Dairy Sci. 93:5300-5308. https://doi.org/10.3168/jds.2010-3154.

Gutierrez, J., C. Barry-Ryan, and P. Bourke. 2009. Antimicrobial activity of plant essential oils using food model media: Efficacy, synergistic potential and interactions with food components. Food Microbiol. 26:142-150. https://doi.org/10.1016/j.fm.2008.10.008.

Hassanat, F., R. Gervais, and C. Benchaar. 2017. Methane production, ruminal fermentation characteristics, nutrient digestibility, nitrogen excretion, and milk production of dairy cows fed conventional or brown midrib corn silage. J. Dairy Sci. 100:2625-2636. https:// doi.org/10.3168/jds.2016-11862.
Horky, P., S. Skalickova, K. Smerkova, and J. Skladanka. 2019. Essential oils as additives: Pharmacokinetics and potential toxicity in monogastric animals. Animals (Basel) 9:352. https://doi.org/10 .3390/ani9060352.

Hristov, A. N., C. Lee, T. Cassidy, K. Heyler, J. A. Tekippe, G. A. Varga, B. Corl, and R. C. Brandt. 2013. Effect of Origanum vulgare L. leaves on rumen fermentation, production, and milk fatty acid composition in lactating dairy cows. J. Dairy Sci. 96:1189-1202. https://doi.org/10.3168/jds.2012-5975.

Hristov, A. N., C. Lee, R. Hristova, P. Huhtanen, and J. L. Firkins. 2012. A meta-analysis of variability in continuous-culture ruminal fermentation and digestibility data. J. Dairy Sci. 95:5299-5307. https://doi.org/10.3168/jds.2012-5533.

Hristov, A. N., J. K. Ropp, S. Zaman, and A. Melgar. 2008. Effects of essential oils on in vitro ruminal fermentation and ammonia release. Anim. Feed Sci. Technol. 144:55-64. https://doi.org/10 .1016/j.anifeedsci.2007.09.034.

Ipharraguerre, I. R., and J. H. Clark. 2003. Usefulness of ionophores for lactating dairy cows: A review. Anim. Feed Sci. Technol. 106:39-57. https://doi.org/10.1016/S0377-8401(03)00065-8.

Jenkins, T. C., V. Fellner, and R. K. McGuffey. 2003. Monensin by fat interactions on trans fatty acids in cultures of mixed ruminal microorganisms grown in continuous fermentors fed corn or barley. J. Dairy Sci. 86:324-330. https://doi.org/10.3168/jds.S0022 -0302(03)73609-1.

Juven, B. J., J. Kanner, F. Schved, and H. Weisslowicz. 1994. Factors that interact with the antibacterial action of thyme essential oil and its active constituents. J. Appl. Bacteriol. 76:626-631. https:/ /doi.org/10.1111/j.1365-2672.1994.tb01661.x.

Khorrami, B., A. R. Vakili, M. Danesh Mesgaran, and F. Klevenhusen. 2015. Thyme and cinnamon essential oils: Potential alternatives for monensin as a rumen modifier in beef production systems. Anim. Feed Sci. Technol. 200:8-16. https://doi.org/10.1016/j .anifeedsci.2014.11.009.

Klevenhusen, F., J. O. Zeitz, S. Duval, M. Kreuzer, and C. R. Soliva. 2011. Garlic oil and its principal component diallyl disulfide fail to mitigate methane, but improve digestibility in sheep. Anim. Feed Sci. Technol. 166-167:356-363. https://doi.org/10.1016/j anifeedsci.2011.04.071

Kolling, G. J., S. C. B. Stivanin, A. M. Gabbi, F. S. Machado, A. L. Ferreira, M. M. Campos, T. R. Tomich, C. S. Cunha, S. W. Dill, L. G. R. Pereira, and V. Fischer. 2018. Performance and methane emissions in dairy cows fed oregano and green tea extracts as feed additives. J. Dairy Sci. 101:4221-4234. https://doi.org/10.3168/ jds.2017-13841.

Lemosquet, S., S. Rigout, A. Bach, H. Rulquin, and J. W. Blum. 2004. Glucose metabolism in lactating cows in response to isoenergetic infusions of propionic acid or duodenal glucose. J. Dairy Sci. 87:1767-1777. https://doi.org/10.3168/jds.S0022-0302(04)73332 $-9$.

Macheboeuf, D., D. P. Morgavi, Y. Papon, J. L. Mousset, and M. Arturo-Schaan. 2008. Dose-response effects of essential oils on in vitro fermentation activity of the rumen microbial population. Anim. Feed Sci. Technol. 145:335-350. https://doi.org/10.1016/j .anifeedsci.2007.05.044.

Martínez, S., J. Madrid, F. Hernández, M. D. Megías, J. A. Sotomayor, and M. J. Jordán. 2006. Effect of thyme essential oils (Thymus hyemalis and Thymus zygis) and monensin on in vitro ruminal degradation and volatile fatty acid production. J. Agric. Food Chem. 54:6598-6602. https://doi.org/10.1021/jf060985p.

Morgavi, D. P., C. Martin, J.-P. Jouany, and M. J. Ranilla. 2012 Rumen protozoa and methanogenesis: Not a simple cause-effect relationship. Br. J. Nutr. 107:388-397. https://doi.org/10.1017/ S0007114511002935.

National Research Council. 2001. Nutrient Requirements of Dairy Cattle. 7th rev. ed. Natl. Acad. Press, Washington DC

Oba, M., and M. S. Allen. 1999. Evaluation of the importance of the digestibility of neutral detergent fiber from forage: Effects on dry matter intake and milk yield of dairy cows. J. Dairy Sci. 82:589596. https://doi.org/10.3168/jds.S0022-0302(99)75271-9. 
Odongo, N. E., R. Bagg, G. Vessie, P. Dick, M. M. Or-Rashid, S. E. Hook, J. T. Gray, E. Kebreab, J. France, and B. W. McBride. 2007. Long-term effects of feeding monensin on methane production in lactating dairy cows. J. Dairy Sci. 90:1781-1788. https:// doi.org/10.3168/jds.2006-708.

Ogimoto, K., and S. Imai. 1981. Techniques of rumen microbiology. Page 158 in Atlas of Rumen Microbiology. Japan Sci. Soc. Press, Tokyo, Japan.

Patra, A. K., and J. Saxena. 2009. Dietary phytochemicals as rumen modifiers: A review of the effects on microbial populations. Antonie van Leeuwenhoek 96:363-375. https://doi.org/10.1007/ s10482-009-9364-1.

Patra, A. K., and Z. Yu. 2012. Effects of essential oils on methane production and fermentation by, and abundance and diversity of, rumen microbial populations. Appl. Environ. Microbiol. 78:42714280. https://doi.org/10.1128/AEM.00309-12.

Plaizier, J. C., A. Martin, T. Duffield, R. Bagg, P. Dick, and B. W. McBride. 2000. Effect of a prepartum administration of monensin in a controlled-release capsule on apparent digestibilities and nitrogen utilization in transition dairy cows. J. Dairy Sci. 83:29182925. https://doi.org/10.3168/jds.S0022-0302(00)75192-7.

Ramanzin, M., L. Bailoni, S. Schiavon, and G. Bittante. 1997. Effect of monensin on milk production and efficiency of dairy cows fed two diets differing in forage to concentrate ratios. J. Dairy Sci. 80:1136-1142. https://doi.org/10.3168/jds.S0022-0302(97)76040 -5 .

Ranga Niroshan Appuhamy, J. A. D., A. B. Strathe, S. Jayasundara, C. Wagner-Riddle, J. Dijkstra, J. France, and E. Kebreab. 2013. Anti-methanogenic effects of monensin in dairy and beef cattle: A meta-analysis. J. Dairy Sci. 96:5161-5173. https://doi.org/10 $.3168 /$ jds.2012-5923.

Rigout, S., C. Hurtaud, S. Lemosquet, A. Bach, and H. Rulquin. 2003. Lactational effect of propionic acid and duodenal glucose in cows. J. Dairy Sci. 86:243-253. https://doi.org/10.3168/jds.S0022 $-0302(03) 73603-0$.

Russell, J. B., and H. J. Strobel. 1989. Effect of ionophores on ruminal fermentation. Appl. Environ. Microbiol. 55:1-6. https://doi.org/10 .1128/AEM.55.1.1-6.1989.

Seal, C. J., and C. K. Reynolds. 1993. Nutritional implications of gastrointestinal and liver metabolism in ruminants. Nutr. Res. Rev. 6:185-208. https://doi.org/10.1079/NRR19930012.
Sylvester, J. T., S. K. Karnati, B. A. Dehority, M. Morrison, G. L. Smith, N. R. St-Pierre, and J. L. Firkins. 2009. Rumen ciliated protozoa decrease generation time and adjust $18 \mathrm{~S}$ ribosomal DNA copies to adapt to decreased transfer interval, starvation, and monensin. J. Dairy Sci. 92:256-269. https://doi.org/10.3168/jds.2008 $-1417$.

Tekippe, J. A., A. N. Hristov, K. S. Heyler, T. W. Cassidy, V. D. Zheljazkov, J. F. S. Ferreira, S. K. Karnati, and G. A. Varga. 2011. Rumen fermentation and production effects of Origanum vulgare L. leaves in lactating dairy cows. J. Dairy Sci. 94:5065-5079. https: //doi.org/10.3168/jds.2010-4095.

Tyrrell, H. F., and J. T. Reid. 1965. Prediction of the energy value of cow's milk. J. Dairy Sci. 48:1215-1223. https://doi.org/10.3168/ jds.S0022-0302(65)88430-2.

Vakili, A. R., B. Khorrami, M. Danesh Mesgaran, and E. Parand. 2013. The effects of thyme and cinnamon essential oils on performance, rumen fermentation and blood metabolites in Holstein calves consuming high concentrate diet. Asian-Aust. Asian-Australas. J. Anim. Sci. 26:935-944. https://doi.org/10.5713/ajas.2012.12636.

Van Soest, P. J., J. B. Robertson, and B. A. Lewis. 1991. Methods for dietary fiber, neutral detergent fiber, and non-starch polysaccharides in relation to animal nutrition. J. Dairy Sci. 74:3583-3597. https://doi.org/10.3168/jds.S0022-0302(91)78551-2.

Weatherburn, M. 1967. Phenol-hypochlorite reaction for determination of ammonia. Anal. Chem. 39:971-974. https://doi.org/10 $.1021 /$ ac60252a045.

Williams, A. G., and G. S. Coleman. 1992. The Rumen Protozoa. Springer-Verlag, New York, NY.

Yang, C., M. A. K. Chowdhury, Y. Huo, and J. Gong. 2015. Phytogenic compounds as alternatives to in-feed antibiotics: Potentials and challenges in application. Pathogens 4:137-156. https://doi .org/10.3390/pathogens4010137.

Yang, W. Z., B. N. Ametaj, C. Benchaar, and K. A. Beauchemin. 2010. Dose response to cinnamaldehyde supplementation in growing beef heifers: Ruminal and intestinal digestion. J. Anim. Sci. 88:680-688. https://doi.org/10.2527/jas.2008-1652.

\section{ORCIDS}

C. Benchaar @ https://orcid.org/0000-0002-8644-6892 